Modern Asian Studies 52, 3 (2018) pp. 849-882. (C) Cambridge University Press 2018 doi:10.1017/Soo26749X16000500

\title{
Fragmented Public Authority and State Un/making in the 'New' Republic of Nepal'
}

\author{
ANDREA J. NIGHTINGALE
}

Department of Urban and Rural Development, Swedish University for Agricultural Sciences (SLU)

Department of International Environment and Development Studies (Noragric),

Norwegian University of Life Science (NMBU)

Email: andrea.nightingale@slu.se

\section{ANIL BHATTARAI}

Department of Geography, University of Toronto

Email: anilbhattarai@gmail.com

\section{HEMANT R. OJHA}

School of Social Sciences, Faculty of Arts and Social Sciences, The University of New South Wales

Email:h.ojha@unsw.edu.au

\section{TULASI SHARAN SIGDEL}

Nepal Administrative Staff College

Email: tsigdel@gmail.com

\section{KATHARINE N. RANKIN}

Department of Geography, University of Toronto

Email:rankin@geog.utoronto.ca

\footnotetext{
* The authors would like to acknowledge the important contributions of Pushpa Hamal, Sabin Ninglekhu, and Fraser Sugden to some of the empirical material that support this article. Conversations with Bharat Pokarel, Naya Sharma Paudel, Bhaskar Vira, Manohara Khadka, Dinesh Paudel, Basundhara Bhattarai, Dil Khatri, and Krishna Shrestha have greatly enhanced our understanding over many years. The research for this article has been supported by grants and awards since 2004, including: a British Academy International Partnership and Mobility Award
} 


\section{Abstract}

Questions of state formation and public authority have been at the top of the development and political agenda in Nepal since 20o6. The post-20o6 so-called 'political transition' has been characterized by rising ethnic tensions, violence, strikes, and a bewildering kaleidoscope of leaders gaining political leverage, only to be marginalized again. In 2015 , the Constitution was finally adopted following the earthquakes and amid violent protests from groups who felt their needs were marginalized in the final version. In this article we are concerned to probe how struggles over different technologies of government help throw into relief the various terrains within which public authority is claimed and contested, and, as a result, help to expose the limits of the state. Using the forestry sector as an ethnographic lens, we argue that there is both a profound failure by the state to provide services and stable governance as well as an ability to reproduce itself and to function in some contexts. It is therefore important to understand public authority during this period as both stable and unstable - and at times, instability is what helps to perpetuate particular imaginaries of the Nepali state.

\section{Introduction}

Why are you talking about state building? The state is being un-built!

-Nepali intellectual at our 'Landscapes of Democracy' workshop, Kathmandu, 2010.

There are numerous problems. Jajarkot [District] is suffering an epidemic. Kathmandu is suffering [G]onstitution. No one is to blame. We did not develop any system except sycophancy.

-Journalist, Kishore, Nepal, 2012. ${ }^{1}$

Today, one of the interesting features of Nepal's politics is the extent to which most people express a very strong desire for the state. Its absence is lamented, its presence expected, and, increasingly, evidence of its functioning - or non-functioning — is pinned on visible technologies of 'development': roads, schools, electricity, health care, and, at the

(2012-2016); a Vetenskapsrådet grant 2015-03323; an IDRC-supported project on 'Research on Knowledge Systems (RoKS)' (Grant no.: 101678-oo3)-2006; an IDRC CIFOR-led research project, 'Enhancing Livelihoods and Equity in Community Forestry in Nepal: the Role of Adaptive Collaborative Management' (2004-2007); a Royal Society of Edinburgh Award, two Royal Geographical Society Small Grants, and a Canadian SSHRC International Opportunities Fund Award (2010-2011). Nightingale's 1990 os grants also supported some of the work presented here: a US National Science Foundation (NSF) Graduate Fellowship, National Science Foundation Doctoral Dissertation Improvement Grant No. 9900788, a FulbrightHays Doctoral Dissertation Award, a Doctoral Dissertation Fellowship from the University of Minnesota Graduate School, and the MacArthur Scholars Program on Global Change, Sustainability and Justice.

${ }^{1}$ https://www.facebook.com/kishorenepal201 2, [accessed 9 February 2018 ]. 
time of writing, effective disaster response after the earthquake. We therefore have a burden to explain just what it is that constitutes public authority and 'the state' in Nepal, and how this imaginary has been sustained over time and in the face of its many failures. We argue that there is both a profound failure by the state to provide services and stable government as well as an ability to reproduce itself and to function in some contexts. Thus, it is important to understand public authority (the governing and ordering of public resources and relationships) during this period as both stable and unstable-and at times, instability is what helps to perpetuate particular imaginaries of the Nepali state as a governing body.

Questions of state formation and public authority have been at the top of the development and political agenda in Nepal since 2006. Nepal's political history is a complex one, and making sense of it requires recognizing that the imaginary of a Nepali state can be traced back to at least the eighteenth century when the country was unified under a king. Nepal was not colonized by the British; rather, in the mid-nineteenth century a Nepali aristocratic oligarchy-the Rana family-seized power from the king and ruled for just over a hundred years. In 1950, the royal family, operating closely with a democratic alliance, took power from the Ranas and established a form of constitutional monarchy. This alliance was terminated in $195^{6}$ when the king took absolute control and established the socalled democratic 'partyless' Panchayat system (nirdaliya panchayati vyavastha). This was characterized by a growing state bureaucracy and violent repression of political dissent, but also a gradual reduction in the extortionate taxes the Ranas had levied from the primarily rural peasantry.

Political dissent, while driven underground, was alive and well, however, and in 1990, the first jana andolan or People's Movement overthrew the monarchy. A constitutional monarchy was established that gave most political power to the parliament and prime minister but retained some limited roles for the monarchy. A civil war-the Maoist People's War-initiated by the Communist Party of NepalMaoist (CPN-Maoist) in 1996 sufficiently destabilized the already contentious democratic political processes to enable the king to seize executive powers in 2004. This attempt was very short-lived, and the second jana andolan successfully re-established democratic institutions and marked the end of the civil war in 2006.

Constituent Assembly elections were held in 2008, and the Maoists won enough votes to begin leading the government through the 
constitution-writing phase. On 28 May 2008, at the first sitting of the Constituent Assembly, Nepal was declared a republic, abolishing the 246-year-old monarchy. As in most places, however, the 'state transition' has not been smooth or conflict free. ${ }^{2}$ Rather, the pattern of infighting and competition for authority at the national level, established after 1990, escalated. ${ }^{3}$

The post-2006 period has been fraught, with rising ethnic tensions, violence, strikes, and a bewildering kaleidoscope of leaders gaining political leverage, only to be marginalized again. In 2015 the Constitution was finally adopted, following the earthquakes and amid violent protest from groups who felt their needs were marginalized in the final version.

In this article we are concerned to probe how struggles over different technologies of government in relation to this political history help throw into relief the various terrains within which public authority is claimed and contested, and, as a result, help to expose the limits of the state. Our research shows that, on the one hand, we can identify 'a state' that has at least partially continued to govern and, on the other hand, we see a changing constellation of institutions, actors, and practices through which public authority has been dispersed from the conventional centres of authority of repressive and autocratic governments. Therefore, we seek to explain first, how and why a recognizable 'Nepali state' has continued to exist in the face of major political upheavals intended to reconstruct it and, second, how legitimacy to govern is reshaped in the face of competition for authority at all levels by old and new actors and institutions. We argue that, despite the sense that the Nepali state is being 'un-built', new modes of public authority are emerging, which are fluid, opportunistic, and, in many respects, quite diverse across different places in Nepal.

In the context of 'political transition', political elites have (re)created ways of legitimating public authority, particularly the

${ }^{2}$ Jha, P. Battles of the New Republic: A Contemporary History of Nepal. London: Hurst, 2014. Shneiderman, Sara and Louise Tillin. 'Restructuring States, Restructuring Ethnicity: Looking Across Disciplinary Boundaries at Federal Futures in India and Nepal'. Modern Asian Studies 49, no. 1 (2015), pp. 1-39.

${ }^{3}$ The Maoists did not remain in power for long: after nine months a new government formed under the coalition partner, United Marxist Leninist (UML), a centre-left party. A detailed discussion of the changing constellation of party coalitions in the post-2008 period is outside the scope of this article, but it is important to recognize that constant struggles are ongoing at the national level. 
'politics of consensus', ${ }^{4}$ wherein authority to govern is negotiated by an increasing array of political agents operating within and beyond the formal government apparatus, but who all share a sense that they will benefit from collusion rather than from forms of oppositional politics. ${ }^{5}$ How that collusion takes place is an ethnographic question and one which has shifted continually in the course of our research. It is precisely this mix of recognizable ways in which actors try to exercise authority and the increasing array of contexts and political agents who are attempting to do so that underpins our argument: namely, that the state continues to persist in a surprisingly recognizable form and yet we cannot overlook the very significant transformations that have taken place. ${ }^{6}$

We follow Tania Li, Akhil Gupta, Jonathan Spencer, and others in tracing the actors, practices, and contexts through which the authority to govern is constituted in order to understand the state and public authority, ${ }^{7}$ using the forestry sector as an ethnographic lens. ${ }^{8}$ Our analysis begins with the now-familiar insight that 'the state' is not the sole source of public authority and that 'governance' occurs in multiple contexts, at different scales. ${ }^{9}$ As Nepal's forestry

\footnotetext{
${ }^{4}$ Byrne, Sarah and Gitta Shrestha. 'A Compromising Consensus? Legitimising Local Government in Post-Conflict Nepal'. International Development Planning Review 36, no. 4 (2014), pp. 435-53. Snellinger, Amanda. 'The Production of Possibility Through an Impossible Ideal: Consensus as a Political Value in Nepal's Constituent Assembly'. Constellations 22, no. 2 (2015), pp. 233-45.

${ }^{5}$ Ojha, Hemant R., Sharad Ghimire, Adam Pain, Andrea Nightingale, Dil B. Khatri and Hari Dhungana. 'Policy Without Politics: Technocratic Control of Climate Change Adaptation Policy Making in Nepal'. Climate Policy 16, no. 4 (2016), pp. $4^{1} 5^{-}$ 33 .

${ }^{6}$ See also, Byrne, S., A. J. Nightingale and B. Korf. 'Making Territory: War, Post-war and the Entangled Scales of Contested Forest Governance in Mid-Western Nepal'. Development and Change 47 no. 6 (2016), pp. 1269-293.

${ }^{7}$ Hoffman, Kasper and Thomas Kirk. Public Authority and the Provision of Public Goods in Conflict-Affected and Transitioning Regions. In Justice and Security Research Programme, Working Paper Series. London: London School of Economics, 2013, pp. 1-58. Li, Tania. The Will to Improve: Governmentality, Development, and the Practice of Politics. Durham: Duke University Press, 2007. Li, Tania Murray. 'Compromising Power: Development, Culture, and Rule in Indonesia'. Cultural Anthropology 14, no. 3 (1999), pp. 295-322. Spencer, Jonathan. 'Performing Democracy and Violence, Agonism and Community, Politics and not Politics in Sri Lanka'. Geoforum 43, no. 4 (2012), pp. 725-31.

${ }^{8}$ See also Sivaramakrishnan, K. Modern Forests: Statemaking and Environmental Change in Colonial Eastern India. Stanford: Stanford University Press, 1999.

${ }^{9}$ Hansen, Thomas Blom and Finn Stepputat. 'Sovereignty Revisited'. Annual Review of Anthropology 35, no. 1 (2006), pp. 295-315. Hansen, T. B. and F. Stepputat. States of Imagination: Ethnographic Explorations of the Postcolonial State. Durham and London: Duke University Press, 2001. Hoffman and Kirk, 'Public Authority and the
} 
sector has passed through a number of reforms and been subject to international policy influence over the past few decades, the number of actors who have a stake in its governance have proliferated, to include: the government bureaucracy, community-based user-groups, national civil society coalitions, timber contractors, international donors, conservation groups, internationally driven climate change adaptation and mitigation programmes, and both state- and NGOsponsored disaster risk management projects. As a result, the forestry sector offers a microcosm of the range of actors, institutions, and practices through which public resources are currently governed in Nepal and, by extension, the emergence and contestation of public authority and the state itself.

One example is illustrative: we see 'civil society' taking public authority into its own hands, both by demanding a stake in formal government practices as well as by delivering services and governance of necessary resources such as forests and water. In some respects, this is not new, as there is a centuries-long history of local community groups managing resources for subsistence, which can be read as 'civil society governance'. However, the recent involvement of aid agencies, enabling legislation, and penetration of markets have created opportunities for the emergence of more formal 'civil society organizations' (NGOs) to take over community governance. It is these formal institutions that claim their place at the political table to represent 'civil society'. The incorporation of NGOs in political processes has also affected activist movements for rights and inclusion which sprang up immediately after 1990. Indeed, one interesting question is the extent to which self-proclaimed 'civil society' groups in Nepal are able to act in opposition to the top-down exercise of state authority (i.e. through an activist role), or whether they become yet another mechanism to impose centralized public authority on local people. These and similar negotiations reassemble the configurations of actors, institutions, and practices through which governing is exercised. In some sense they are difficult to track, but nevertheless are reasonably predictable in terms of their implications for public

Provision of Public Goods'. Lund, Christian. Twilight Institutions: Public Authority and Local Politics in Africa. Oxford: Blackwell, 2007. Raeymaekers, Timothy, K. Menkhaus and Koen Vlassenroot. 'State and Non-State Regulation in African Protracted Crises: Governance without Government?'. Afrika Focus 21, no. 2 (2008), pp. 7-21. Vandekerckhove, Nel. 'The State, the Rebel and the Chief: Public Authority and Land Disputes in Assam, India'. Development and Change 42, no. 3 (201 1), pp. 759-79. 
authority. Our analysis thus seeks to map this simultaneous fracturing and cementing of the political landscape by examining which actors are pulled into different moments of governing, and how they engage in governance.

Our discussion begins by positioning our argument in relation to the wider literature on the state, public authority, and the political ecology of resource governance. In order to situate the 2006 revolution and subsequent period, we recount a brief history of the state in Nepal and forest governance. We then explore the actors, practices, and institutions of the forestry sector to show the shifting landscape of public authority in the post-2006 period until the time of writing (2016). Through this analysis, we offer conceptual insights into the Constitution and enactment of public authority that can be applied to other contexts, as well as provide an ethnographic account of state transition in Nepal.

\section{Emerging political nexus: actors, practices, and contexts of public authority}

To make sense of public authority in Nepal, we place particular emphasis on tracing who governs, what practices they use to assert authority, and the contexts through which legitimacy to govern is achieved. Importantly, we understand authority and legitimacy as relationally produced in the everyday practices of governing. Authority must be both asserted and acknowledged in order to be legitimate and sustained $;{ }^{10}$ however, there is a spectrum of practices through which 'acknowledgement' is achieved, including coercion and violence. ${ }^{11}$ We argue that a focus on the actors, practices, and contexts of governance gives us greater insight into how public authority is simultaneously ephemeral and enduring. While we theorize authority as a relation that must be constantly renewed, at the same time, we see a remarkable continuity in some forms.

In the context of Nepal, we are particularly concerned to make sense of the way in which the fracturing of public authority has resulted in a cementing of what is described as an 'iron pentangle' or 'nexus'. The 'iron pentangle' brings together politicians, civil bureaucrats,

${ }^{10}$ Lund, Christian. 'Twilight Institutions: Public Authority and Local Politics'. Development and Change 37, no. 4 (2006), pp. $685-705$.

${ }^{11}$ Hoffman and Kirk, 'Public Authority and the Provision of Public Goods'. 
contractors, local civil society leaders, and user-group leaders into various types of alliances that serve to control resources and many dimensions of governance. In the absence of local democratic elections, these alliances have filled the local governance vacuum, sometimes working pragmatically to use consensus authority to fix problems (such as anti-poaching campaigns around national parks), but most of the time serving to reap undue benefits (such as timber selling) for their participants. At the centre of these alliances are material resources, sometimes high-value timber, and at other times, aid money surrounding project negotiations. Through these politicized relationships, new actors are becoming interested in the material benefits that can be leveraged out of governance arrangements in different sectors, and old alliances that historically controlled those benefits are shifting in order to maintain their stake. ${ }^{12}$ This also leads the dominant government and donor agencies to invite actors who were previously not so powerful into 'multi-stakeholder' and 'participatory' forums in order to negotiate over resource governance schemes. Meanwhile, government politico-administrative institutions continue to experience crises of legitimacy and become less and less functional.

Our analysis has benefited from the debate on 'failed states' in Africa and insights into the nature of public authority that have emerged in that context. We follow those who reject '.. this pathological approach to state institutions in Africa [as] essentialist, teleological and instrumentalist conceptions of state and political authority'. ${ }^{13}$ Many scholars show how governance proceeds at different levels and through a constellation of actors who employ state-like tactics, including taxation, violence, delivery of services, and issuing of property titles, among other practices that serve to secure their legitimacy to govern. ${ }^{14}$ Given the increasing sense by both inside and outside observers in Nepal that the state is 'totally dysfunctional', as

${ }^{12}$ See also Vandekerckhove, 'The State, the Rebel and the Chief'.

${ }^{13}$ Hagmann, Tobias and Didier Péclard. 'Negotiating Statehood: Dynamics of Power and Domination in Africa'. Development and Change 41, no. 4 (2010), pp. 539-62, here p. 541 .

${ }^{14}$ Ferguson, James. Global Shadows: Africa in the Neoliberal World Order. Durham: Duke University Press, 20o6. Ferguson, James and Akhil Gupta. 'Spatializing States: Toward an Ethnography of Neoliberal Governmentality'. American Ethnologist 29, no. 4 (2002), pp. 981-1002. Hagmann, Tobias. 'Beyond Clannishness and Colonialism: Understanding Political Disorder in Ethiopia's Somali Region, 1991-2004'. Modern African Studies 43, no. 4 (2005), pp. 509-36. Hagmann and Péclard, 'Negotiating Statehood'. Lund, Twilight Institutions. Raeymaekers, Menkhaus and Vlassenroot, 
the quotes at the beginning of this article suggest, it is timely to bring these insights to bear on Nepal. Public authority and state formation processes are constantly being made and un-made, creating both state failures and successes, and fracturing as well as providing continuity in governance. The 'failed state' lens is too narrow to understand Nepal. ${ }^{15}$ We need to explain the way in which it has (at least in part) continued to function since 2006 under conditions of legal ambiguity and excessive competition for power. We therefore probe in what sense public authority continues to function and what that tells us about state formation.

Underpinning our understanding of the state is Timothy Mitchell's assertion that ' $\mathrm{t}]$ he ability to have an internal distinction appear as though it were the external boundary between separate objects is the distinctive technique of the modern political order' ${ }^{16}$ He uses this insight to argue that attention to the mechanisms of governance (particularly various developmental aspirations) brings into view how 'the state' emerges as an entity distinct from society. It is not the case that the state is outside of society, rather, it is how the state comes to be framed as unique and separate from other institutions in society, that is a particular achievement of state-like forms. ${ }^{17}$ As we elaborate below, in Nepal we see very clearly how the state has achieved this separation, stretching back to at least the nineteenth century under a series of kings and other autocratic rulers. Thus, the state imaginary in Nepal has a much longer history than its other South Asian neighbours, which tend to pin their origins as modern states to the retreat of British rule.

Given that Nepal has managed to retain an identity as a state body for more than two centuries now, ${ }^{18}$ it is crucial to attend to

'State and Non-State Regulation'. Vandekerckhove, 'The State, the Rebel and the Chief'.

${ }^{15}$ Burghart, Richard. The Conditions of Listening: Essays on Religion, History, and Politics in South Asia. Delhi: Oxford University Press, 1996. Tamang, Seira. 'Exclusionary Processes and Constitution Building in Nepal'. International Journal on Minority and Group Rights 18, no. 3 (201 1), pp. 293-308.

${ }^{16}$ Mitchell, Timothy. 'The Limits of the State: Beyond Statist Approaches and Their Critics'. American Political Science Review 85, no. 1 (1991), p. 78.

${ }^{17}$ Ibid.

${ }^{18}$ Joshi, Bhuwan Lal and Leo E. Rose. Democratic Innovations in Nepal: A Case Study of Political Acculturation. Berkeley: University of California Press, 1966. Regmi, Mahesh C. An Economic History of Nepal I846-I9or. Varanasi: Nath Printing House, 1988. Regmi, M. C. Landownership in Nepal. Delhi: Adroit Publishers, 1977. Regmi, M. C. Kings and Political Leaders of the Gorkhali Empire, I768-I8I4. Hyderabad: Orient 
'the elusiveness of the state-society boundary... not as a problem of conceptual precision but as a clue to the nature of the phenomenon'. ${ }^{19}$ Here we follow Tania $\mathrm{Li}^{20}$ and Jonathan Spencer ${ }^{21}$ in focusing attention on the role of spectacular moments which serve to throw into relief relations that can otherwise become obscured by habit and everyday, often hidden, repetition. In other words, our attention is less on what the Nepali state is and more on how public authority is accomplished, by whom, and whether people attribute such achievements to 'the government' or to some other entity like 'civil society'.

We add to these conceptual insights from anthropology and political science a particular focus on the importance of the physical landscape as both a terrain and symbolic domain for state action. Within geography, a number of political ecologists have demonstrated how the state, resources, and citizens are co-produced. ${ }^{22}$ Neumann has argued that states are constructed by processes of mapping, bounding, and containing territories, nature, and citizens for the governance of resources. ${ }^{23}$ We extend this analysis by showing how projects intended to improve the material base of the state quite literally build the state. The relationships required to achieve various kinds of resource governance serve to constitute, and place in relationship to each other, state bureaucrats, civil society institutions, and ordinary citizens. In addition, through resource control, the state extends its

Longman, 1995. Whelpton, John. A History of Nepal. Cambridge: Cambridge University Press, 2005.

${ }^{19}$ Mitchell, 'The Limits of the State', p. 78.

${ }^{20} \mathrm{Li}$, 'Compromising Power', p. 295.

${ }^{21}$ Spencer, Jonathan. Anthropology, Politics, and the State: Democracy and Violence in South Asia. Cambridge: Cambridge University Press, 2007.

${ }^{22}$ Peluso, Nancy Lee. 'Emergent Forest and Private Land Regimes in Java'. Journal of Peasant Studies 38, no. 4 (2011), pp. 811-36. Peluso, N. 'Rubber Erasures, Rubber Producing Rights: Making Racialized Territories in West Kalimantan, Indonesia'. Development \& Change 40, no. 1 (2009), pp. 47-80. Peluso, N. 'Whose Woods are These? Counter-Mapping Forest Territories in Kalimantan, Indonesia'. Antipode 27, no. 4 (1995), pp. 383-406. Watts, Michael J. 'Antinomies of Community: Some Thoughts on Geography, Resources and Empire'. Transactions of the Institute of British Geographers 29, no. 2 (2004), pp. 195-216.

${ }^{23}$ Neumann, Roderick P. 'Nature-State-Territory: Toward a Critical Theorization of Conservation Enclosures'. In Liberation Ecologies: Environment, Development, Social Movements, edited by Richard Peet and Michael Watts. London and New York: Routledge, 2004, pp. 195-2 1 7. Sending, Ole Jacob and Iver B. Neumann. 'Governance to Governmentality: Analyzing NGOs, States, and Power'. International Studies Quarterly $5^{\text {o, no. }} 3$ (2006), pp. $65^{1-72 .}$ 
sovereignty onto the territory of the state $^{24}$ in a tangibly material way. $^{25}$

In Nepal, the historian M. C. Regmi's work has shown how the formation of the Nepali state and the policies and practices of rulers had profound effects on predominantly agrarian households, bringing them into political economic relations with the state, which continue to shape how people are subject to and become involved in practices of public authority today. ${ }^{26}$ We therefore maintain that to make sense of Nepal's politics, it is crucial first to probe the practices of bricolage ${ }^{27}$ and compromise, ${ }^{28}$ which appear to be spontaneous, situated, and opportunistic. These practices contribute to the sense that the current period is a situation of 'permanent transition', as Byrne has suggested, ${ }^{29}$ or 'ad hoc-ism', as Baral characterized the Panchayat era from $195^{\circ}$ to the late 1970 os. ${ }^{30}$ A situation of transition is constantly created and sustained, as it seems that this is the most preferred political economic situation for those seeking to control public authority, including all those within the power pentagon: the ruling party, oppositional parties, civil society avant-gardes, business groups, and international aid agencies.

Burghardt, writing about the pre-1990 Panchayat period, postulated that the state is a 'counterfeit reality', drawing attention to how the 'real' business of the state has always been hidden. ${ }^{31}$ Legal provisions create an illusion of procedural practices and citizens' rights, which, in fact, is not how the state functions in practice. Rather,

${ }^{24}$ Harris, Leila. 'State as Socionatural Effect: Variable and Emergent Geographies of the State in Southeastern Turkey'. Comparative Studies of South Asia, Africa and the Middle East 32, no. 1 (2012), pp. 25-39.

${ }^{25}$ Bridge, Gavin. 'Resource Geographies II: The Resource-State Nexus'. Progress in Human Geography 38, no. 1 (2014), pp. 118-30. Peluso, 'Rubber Erasures'.

${ }^{26}$ Regmi, Landownership in Nepal. Regmi, An Economic History of Nepal. Regmi, M. C. Land Tenure and Taxation in Nepal, Vols 1-4, 2nd ed. Kathmandu: Ratna Pustak Bhandar, 1978.

${ }^{27}$ Hagmann and Péclard, 'Negotiating Statehood'. Cleaver, Frances. 'Reinventing Institutions: Bricolage and the Social Embeddedness of Natural Resource Management'. The European Journal of Development Research 14, no. 2 (2002), pp. 11-30.

${ }^{28}$ Byrne and Shrestha: 'A Compromising Consensus?'.

${ }^{29}$ Byrne, Sarah "From Our Side Rules are Followed": Authorizing Bureaucracy in Nepal's "Permanent Transition" in this special issue, drawing from Wydra, Harald. Continuities in Poland's Permanent Transition. Basingstoke/New York: Macmillan/St Martin's Press, 2000.

${ }^{30}$ Baral, Lok Raj. Oppositional Politics in Nepal. New Delhi: Abhinav Publications, 1977 .

\footnotetext{
${ }^{11}$ Burghart, The Conditions of Listening.
} 
a variety of patronage relationships ${ }^{32}$ and 'backroom deals' are formed and then re-presented in public forums as a kind of performance of governance. Our research shows the latter is particularly true with regard to how political appointments within decision-making institutions are made, how contracts are awarded for infrastructure projects, and how development projects are selected and budgeted for. What is interesting about the status quo is that many of these dynamics are increasingly less veiled. Whereas previously the state and its allies were able to create an imaginary of unity and political coherence, ordinary people are no longer quiet about that imaginary and openly discuss the rampant corruption that the 'iron pentangle' perpetuates.

Burghardt and Regmi based their work on the pre-Panchayat expansion of the state as a set of extractive institutions and the Panchayat system instituted under the monarchy; nevertheless, their work is highly relevant to the situation in Nepal today, in part because of the continuity in form we see in the exercise of public authority. In fact, uncovering the ways in which a variety of presumably deliberative and democratic practices at the local level are staged performances-for example the public discussions of the affairs of community forestry user-groups-is crucial to understanding 'transitional' politics. The public presentation of rule wears a mask of inclusion, distributive justice, and radical politics, yet the day-to-day business of governing is deeply bound up in patronage relationships, exchange of money and favours, and violence. We therefore also argue that it is crucial to show the continuities of rule that are evident in the repetition of cultural codes $\left(\operatorname{doxa}^{33}\right)$ and the remarkable staying power of particular institutions, actors, and practices that seem to (re)cycle themselves in key everyday moments of governing and state restructuring. ${ }^{34}$

Attention to the fragmentation of authority as well as the cementing of particular forms of governing becomes particularly important in violent and contested political contexts such as that created during the civil war in Nepal. During and immediately after the war, the

${ }^{32}$ Nightingale, Andrea J. and Hemant R. Ojha. 'Rethinking Power and Authority: Symbolic Violence and Subjectivity in Nepal's Terai Forests'. Development and Change 44, no. 1 (2013), pp. 29-51.

${ }_{33}$ Bourdieu, Pierre. 'Social Space and Symbolic Space'. In Practical Reason, edited by Pierre Bourdieu. Cambridge: Polity Press, 1998, pp. 1-18.

${ }^{34}$ Nightingale and Ojha, 'Rethinking Power and Authority'. 
Maoists had an explicit ambition to un-make and remake the state ('new Nepal'). ${ }^{35}$ The war was intended to dismantle the physical apparatus of the state, including government offices, police and army posts, and other infrastructure, as well as politically destabilize the legitimacy of the country's public authorities at both the local and national levels, including parliament and the monarchy. ${ }^{36}$ They explicitly sought to drive out elected local leaders (village development committee (VDG) and district development committee (DDC) presidents), and dismantle physical manifestations of state rule and development interventions such as the offices of the Department of Forests, among many other targets. In areas where they achieved adequate control, they established People's Governments (jana sarkaar) and put in place People's Courts to resolve local disputes and dispense justice. ${ }^{37}$ In short, the Maoists used a variety of state-like forms to create an internal distinction between the local community and the People's Governments (in effect legitimating the jana sarkaar) and between the People's Governments and the Nepali state, both of which served to undermine the Nepali state. The practices and symbols employed by the Maoists in their efforts to establish a parallel state help to reveal how public authority within Nepal is constituted and maintained under 'ordinary' conditions as well. ${ }^{38}$ Now, in the transition period, the political parties are again engaged in a struggle over the symbols, practices, and institutions through which governance is achieved, albeit this time under the guise of 'democratic politics'. These same practices and symbols are the crucial mechanisms that have served to maintain the Nepali state in the everyday over a remarkably long period of time, and therefore offer important entry points into an ethnography of state transition.

The fracturing of public authority ${ }^{39}$ appears to be particularly acute in Nepal's recent political history, the disruption caused by

${ }^{35}$ Jha, Battles of the New Republic. Thapa, Deepak. A Kingdom under Siege: Nepal's Maoist Insurgency, I996-2004. London: Zed Books, 2004.

${ }^{36}$ Hutt, Michael (ed.) Himalayan 'People's War': Nepal's Maoist Rebellion. London: C. Hurst and Co., 2004.

${ }^{37}$ Shah, Alpa and Judith Pettigrew. 'Windows into a Revolution: Ethnographies of Maoism in South Asia'. Dialectical Anthropology 33, no. 3-4 (2009), pp. 225-51. Shneiderman, Sara Beth. 'The Formation of Political Consciousness in Rural Nepal'. Dialectical Anthropology 33, no. 3-4 (2009), pp. 287-3o8.

${ }^{38}$ See also Vandekerckhove, 'The State, the Rebel and the Chief' for a parallel case in India.

${ }^{39}$ Lund, Christian. 'Fragmented Sovereignty: Land Reform and Dispossession in Laos'. Journal of Peasant Studies 38, no. 4 (2011), pp. 885-905. Sikor, Thomas and 
the war aside. First, in the 1990s the Nepal government decreed that international donors would be unable to directly implement development projects. Rather, they would have to work through local 'service providers', most often NGOs, to do the actual on-the-ground development work. This means that the provision of development services is often channelled through local NGOs rather than the municipality or village level government (VDC), which in turn work with community user-groups. Secondly, since the early 1990 os local governance in Nepal has been in a period of transition due to the way the politics of representation has been playing out at the local level, particularly after the institution of the Local Self Governance Act 2055 (1999). ${ }^{40}$ This Act, created with support from the United Nations Development Programme (UNDP) and others, authorizes village councils, VDGs, and DDGs to make governance decisions and raise taxes without needing to consult higher-level authorities. (The war meant that many of the provisions in the Act have not been implemented.)

This process of decentralization became even more stagnant after 2000. As the political parties began drafting the new Constitution, they all decided to suspend the system of local governance that was in place while it was being constructed. The Maoists explicitly argued that holding elections for local leaders under the old regime would be tantamount to political regression. The other parties also appear to have been reluctant to devolve power to locallevel governing institutions for disparate reasons, although they did support an increase in local-level budgets. So while some donors and local institutions attempted to draw on provisions in the Local Self Governance Act, it seems the devolution of power is only possible now that local elections have taken place. What is clear, though, is that in the post-1990 context of democratic opening up, straightforward, topdown rule is not as easy as it was during the Panchayat. The actions of the expanded set of actors we have identified have had profound consequences for public authority as government and new actors become involved in areas ranging from natural resource management to infrastructure development and public financing.

Christian Lund. 'Access and Property: A Question of Power and Authority'. Development and Change 40, no. 1 (2009), pp. 1-22.

${ }^{40}$ Government of Nepal (GON). 'Local Self Governance Act 2055', edited by the Government of Nepal. Kathmandu: GON, 1999. 
Finally, the war and its aftermath have sparked new studies into the state, highlighting the limits of political parties in representing people, the persistence of social exclusion in the process of democratic mobilizations, and the restructuring of the state, including the continuing bias against groups that have been historically disadvantaged: Dalits, women, and janajati (indigenous) groups. ${ }^{41}$ While there has been expansion in the areas of life in which state institutions were involved during the 246-plus years of the Nepali state's history, the labyrinth of opaque bureaucratic processes at the everyday level often leads to a situation in which ordinary citizens find it nearly impossible to achieve routine official tasks, including those related to accessing resources from state, without having some kind of personal relationship or local political leverage with government representatives. It is common for political actors to use their leverage in this sphere thereby reproducing long-standing patronage relations. This is understood as 'aphno maanche' or 'one's own people', and across Nepal, people who wish to gain political power or to accomplish community projects seek to make such connections. When trying to make sense of public authority, it is therefore necessary to think through how resource governance creates particular kinds of alliances, practices, and institutions. These relations give us insights into the working of public authority and the mechanisms through which it emerges as legitimate and durable over time and space.

Our discussion draws from the extensive research done on the forestry sector in Nepal by Nightingale (1993-2016) and Ojha (19992016) as well as from the insights gleaned through government jobs and participating in citizen forums by Bhattarai, Ojha, and Sigdel extending back to the mid-199os. We further draw upon qualitative research done by Nightingale and Ojha in seven districts (2012-2016) and the $5^{\mathrm{O}-p l u s}$ qualitative interviews and five months of participant observation done in three districts as part of the 'Landscapes

${ }^{41}$ Gellner, David N. (ed.) Resistance and the State: Nepalese Experiences. New York and Oxford: Berghan Books, 2007. Gellner, D. N. and Krishna Hachhethu. Local Democracy in South Asia: Microprocesses of Democratization in Nepal and its Neighbours. Delhi: Sage, 20o8. Gellner, D. N., Joanna Pfaff-Czarnecka and John Welpton (eds) Nationalism and Ethnicity in a Hindu Kingdom: The Politics of Culture in Contemporary Nepal, Studies in Anthropology and History. Amsterdam: Overseas Publishers Association, 1997. Shneiderman, Sara and Louise Tillin. 'Restructuring States, Restructuring Ethnicity: Looking Across Disciplinary Boundaries at Federal Futures in India and Nepal'. Modern Asian Studies 49, no. 1 (2015), pp. 1-39. Tamang, 'Exclusionary Processes and Constitution Building'. 
of Democracy' project (2009-2011) by Nightingale, Sigdel, and Rankin. ${ }^{42}$ Unless otherwise indicated, the insights about the historical and current practices, actors, and institutions of governance come directly from our field research and personal experiences in Nepal.

\section{A woody history of the Nepali state, 1948-1990}

While the civil war (1996-2006) and the post-20o6 transition period attracted global media attention to politics in Nepal, the history of movements for democracy extends back to at least the 1940s during the period of the Rana oligarchy. The Ranas' rule was characterized by exorbitant taxes which resulted in significant land degradation, massive accumulation of wealth by the country's aristocracy, and violent suppression of the peasantry. ${ }^{43}$

The Ranas used a system of favouritism and decentralized governance, giving land grants to government employees, military leaders, and rural aristocrats to ensure their loyalty. ${ }^{44}$ These mechanisms of governance meant that by 1948 there were landlords with control over resource extraction and who were liable for taxation in very large parts of the country. ${ }^{45}$ These landed elites held a lot of political power, not only nationally but also locally, so that to this day, families descended from former mukiya (village headmen and tax collectors) continue to be privileged in many places and, indeed, many powerful aphno maanche networks are constituted by such people. It is important to mention, however, that not all landed elites were equal. The size and type of land grant depended on the status of the person to whom it was given, ${ }^{46}$ and thus during that time there was also heterogeneity in terms of public authority at the grassroots as

\footnotetext{
${ }^{42}$ Pushpa Hamal was also an important member of the research team. We gratefully acknowledge his contributions to the empirical material.

${ }^{43}$ Whelpton, John. 'Political Violence in Nepal from Unification to Janandolan I: The Background to "People's War"'. In Revolution in Nepal: An Anthropological and Historical Approach to the People's War, edited by Marie Lecomte-Tilouine. Delhi: Oxford University Press, 2013, pp. 27-74. Whelpton, A History of Nepal. Joshi and Rose, Democratic Innovations in Nepal. Regmi, Kings and Political Leaders.

${ }^{44}$ Regmi, Land Tenure and Taxation in Nepal.

${ }^{45}$ Mahat, T. B. S., D. M. Griffin and K. R. Shepherd. 'Human Impact on Some Forests of the Middle Hills of Nepal. Part 2. Some Major Impacts Before 1950 on the Forests of Sindhu Palchok and Kabhre Palanchok'. Mountain Research and Development 6, no. 4 (1986), pp. 325-34.

${ }^{46}$ Regmi, Land Tenure and Taxation in Nepal.
} 
well. Some mukiya were very much part of their communities and were given limited control over forests and tax collection, while others were effectively absentee landlords. ${ }^{47}$ Many mukiya who lived in the locality used intimidation and underlings to exhort taxes from the peasantry. These antecedents remain important today. ${ }^{48}$

Therefore the burgeoning movement for democracy that began in $195^{\circ}$ not only needed to oust the Ranas centrally, but also to dismantle the power of a dispersed and often rural-based ruling class. These efforts were not successful, and by 1960 the king had taken absolute control and the nascent democratic experiment was largely driven underground until the 1990 jana andolan. ${ }^{49}$ Instead, the king instituted the Panchayat system, or 'partyless democracy', which, in effect, was governance by mukiya appointed by the king and by elected pradhan panch (local mayors). The king capitalized on many of the existing rural elites, retaining their status as tax collectors and village headmen-indeed, many of them were elected as pradhan panch. The state thus simultaneously succeeded in centralizing the imaginary of the nation-embodied in the king - and came under increased control by the traditional elites who commanded an even greater degree of public authority by co-opting the ideas of democracy itself.

During this time, forests were centre stage as a key site of state formation and contestations over authority. ${ }^{50}$ The first official forest administration began with the establishment of BanJanch Adda (BJA) in 1934, followed by the Office of the Chief Conservator of Forests in $195^{6}$ during the years of democracy. This was later renamed the Department of Forests in 1976 . In 1957 the king nationalized any land with trees on it (although certain kinds of private property claims were honoured). This has been framed as a conservation move, ${ }^{51}$ but we suggest that the nationalization of forests was motivated by a mix of factors. First, the king was influenced by the post-Bretton

${ }^{47}$ Sugden, Fraser. 'Pre-Capitalist Reproduction on the Nepal Tarai: Semi-Feudal Agriculture in an Era of Globalisation'. Journal of Contemporary Asia 43, no. 3 (2013), pp. $5^{19-45}$.

${ }^{48}$ Field notes; Regmi, Kings and Political Leaders.

${ }^{49}$ Whelpton, A History of Nepal.

${ }^{50}$ Ojha, Hemant R., Mani R. Banjade, Ramesh K. Sunam, Basundhara Bhattarai, Sudeep Jana, Keshab R. Goutam and Sindhu Dhungana. 'Can Authority Change Through Deliberative Politics?: Lessons from the Four Decades of Participatory Forest Policy Reform in Nepal'. Forest Policy and Economics 46, no. o (2014), pp. 1-9.

${ }^{51}$ Gilmour, D. A. and R. J. Fisher. Villagers, Forests and Foresters: The Philosophy, Processes and Practice of Community Forestry in Nepal. Kathmandu: Sahayogi Press, 1991. 
Woods development agenda, and it seems clear the UN's Food and Agriculture Organization (FAO) and the United States Agency for International Development (USAID) both had a role in persuading him to establish the Department of Forests and take control of forested areas. Second, we argue that it was also a mechanism to diminish the authority of the landed aristocracy, as the king and Congress Party political elites were trying to establish a new form of rule. The move extended the king's sovereignty into the farthest reaches of the kingdom by dispossessing landed elites of a large part of their landholdings. Third, the establishment of forest offices across the country throughout the 1960 s and 1970 save the state a material, tangible, and, importantly, personal face in remote areas. ${ }^{52}$ It is in this sense that forests came to represent the state (and development). The Panchayat-era nationalistic slogan, 'Nepal's wealth is her green forests' [Hariyo Ban, Nepalko Dhan] captures that sense perfectly.

The forest offices were therefore an important technology of rule through which the king could 'govern at a distance', ${ }^{53}$ just as the Ranas had used land grants to achieve the same end. Forest offices were one of the institutions through which public authority was brought under the guise of the central state. The forest (and other district) offices also marked a distinct departure in the logic of public authority. Rather than relying on semi-autonomous local leaders, who were often only resident for part of the year in their domains, the king invested in the civil bureaucracy. District forest officers and rangers, required to have a specific technical qualification and appointed through a centralized selection process, took on a variety of governance functions in relation to protecting and managing the sovereign's forest resources. In these ways the Department of Forests represented both a departure from the Rana system of public authority, while also cementing some of its practices, particularly those of favouring elites by giving them control over resources (now as government bureaucrats).

The Department of Forests also represented a relatively new institution through which international notions of scientific forest management and conservation were promoted, mainly through

\footnotetext{
${ }^{52}$ At this time, district headquarters were also established. Our remarks here on establishing a state presence in remote areas pertain to those offices as well.

${ }^{53}$ Foucault, Michel. 'Governmentality'. In The Foucault Effect: Studies in Governmentality, edited by Graham Burchell, Colin Gordon and Peter Miller. Chicago: University of Chicago Press, 1991, pp. 87-104.
} 
recruiting foresters trained in classic Indian forestry institutions set up by the British regime. Perhaps most importantly, the foresters were moved frequently. Indeed, it continues to be a policy of the civil service to move bureaucrats regularly in order for new governments to exercise power (e.g. people who support the ruling party are given more favourable appointments). This simultaneously has the effect of providing opportunities for rent seeking at all levels of this process. Note the remarkable continuity of maintaining a dispersed yet centrally controlled public authority over forests between the Ranas' land grant system and the opportunities for rent seeking offered by district forest office posts in places where forest resources (timber or medicinal herbs) command high values. These practices pertain to higher level government officials, while lower level civil servants in district forest offices (below the level of district forest officer and rangers) are still relatively locally based, although they are also recruited through the Public Service Commission's centralized system.

In the 1970s, the governance of Nepal's forests again became a global concern, this time due to land degradation. The World Bank, FAO, and several donors, particularly the Australians, declared that by the millennium all hillsides in Nepal would be devoid of forests ${ }^{54}$ and urgent measures were needed to salvage the situation. This so-called 'Theory of Himalayan Environmental Degradation' (or THED) ${ }^{55}$ provided the justification for numerous donor-funded forestry projects, including community forestry and protected areas. Later, leasehold forestry, collaborative forestry, and buffer zone projects were also instituted, ostensibly to address the needs of marginalized people, the complexities of forest claims in the Terai (southern lowlands), and the areas immediately outside protected areas, respectively. ${ }^{56}$

Forestry projects in the 198 os were initially aimed at afforestation through plantations. Early experiments, however, had abysmal success

${ }^{54}$ Eckholm, E. P. 'The Deterioration of Mountain Environments'. Science 189 (1975), pp. 764-70.

${ }^{55}$ Ives, Jack D. and Bruno Messerli. The Himalayan Dilemma. Reconciling Development and Conservation. London and New York: The United Nations University and Routledge, 1989. Metz, John. 'Downward Spiral? Interrogating Narratives of Environmental Change in the Himalaya'. In Culture and the Environment in the Himalaya, edited by Arjun Guneratne. London and New York: Routledge, 2010, pp. 17-39.

${ }^{56}$ Ojha, Hemant R., N. Timsina, C. Kumar, B. Belcher and M. Banjade. Communities, Forests and Governance: Policy and Institutional Innovations from Nepal. India: Adroit Publishers, 2008. 
rates and, thanks to extensive research by the Australian forestry project and their Nepali colleagues, it was concluded that the problems were not technical forestry issues, but rather a lack of engagement by local people. ${ }^{57}$ Without the support of village headmen, plantations were sabotaged and success rates were very low. ${ }^{58}$ Moreover, the plantations did not create forests that fulfilled the varied needs of residents such as fodder, firewood, and construction materials. ${ }^{59}$ Projects were therefore redesigned to include a measure of community control and sought especially to engage elites in the management of what became known as 'community forestry user-groups' (CFUGs). Very quickly, the narrative and practices within community forestry shifted from the initial emphasis on trees, to one of equity, inclusion, and resource access for the poorest of the poor.

With support from donors and various bilateral projects, the formation of new user-groups around many accessible patches of forest was initiated from the late 1980 os to the 2000 . Interestingly, even the 'undemocratic' Panchayat political system allowed this change in the institutions authorized to govern forests, presumably in the belief that this was not a political process but simply an environmental one, involving some development incentives to local communities. It is important to note here, however, that the experiments prior to 1993 (see below) were limited to a few forests and districts due to resistance from the forest bureaucracy and fears by the Panchayat rulers that decentralizing too much control over such a symbolic and economically important part of the state would undermine their rule.

\section{Post-1990: participation, fractured authority, and the rise of the iron pentangle}

Why do you want to make our rani ban (Queen's forest) a community forest? We do not want our forest to be taken by the government in the name of community forest. The forest is already ours and we not want rangers and

${ }^{57}$ Gilmour and Fisher, Villagers, Forests and Foresters.

${ }^{58}$ Mahat, T. B. S., D. M. Griffin and K. R. Shepherd. 'Human Impact on Some Forests of the Middle Hills of Nepal. Part 3. Forests in the Subsistence Economy of Sindhu Palchok and Kabhre Palanchok'. Mountain Research and Development 7, no. 1 (1987), pp. 53-70.

${ }^{59}$ Mahat, T. B. S., D. M. Griffin and K. R. Shepherd. 'Human Impact on Some Forests of the Middle Hills of Nepal. Part 4. A Detailed Study in the Southeast Sindhu Palchok and Northeast Kahbre Palanchok'. Mountain Research and Development 7, no. 2 (1987), pp. $111-34$. 
forest guards to come to our village to tell us what to do and what not to do. We know how to manage our forests.

Elderly man, Baglung District, 2000.

Overall, public authority during the Panchayat regime was characterized by the careful maintenance of a 'counterfeit reality' 60 wherein political dissent was violently suppressed and a veneer of national unity was promoted through radio, schools, and national spectacles such as the king and queen's high-profile visits to remote rural areas in their helicopter. ${ }^{61}$ Yet beneath this veneer of stability, political mobilization against the Panchayat system was gaining momentum. Throughout the period, political leaders who had been driven underground (and to India) in the $195^{\circ}$ os were still operating within Nepal, while regional political configurations that placed Nepal's economy very much at the mercy of India and China also influenced the political mood. A series of smaller protests and underground activism in the 1970 s and 1980 os culminated in the 1990 jana andolan. ${ }^{62}$ The monarchy ceded power to the political parties, and a Westminster parliamentary model of democracy was instituted in one of the first of several fairly radical reconfigurations of the basis for public authority in modern Nepal.

The shifting basis of public authority provided an opportunity for national level community forestry (CF) actors-already grown into a critical mass— to influence the Forest Act 1993 (1996). ${ }^{63}$ While it was an early and significant achievement for the new multiparty democracy to shape the terms of environmental governance, it also exemplifies the profound change in the nature of public authority at this time. It marked the beginning of civil society demanding a stake in governmental law-making, policy processes, and even programme planning. The Act itself is considered to be one of the most progressive

${ }^{60}$ Burghart, The Conditions of Listening.

${ }^{61}$ Adhikari, Kamal. 'Naming Ceremonies as Rituals of Development'. Studies in Nepali History and Society 1, no. 2 (1996), pp. 245-364. See also field notes.

${ }^{62} \mathrm{Jha}$, Battles of the New Republic; Gellner, Resistance and the State; Gellner, PfaffCzarnecka and Welpton (eds) Nationalism and Ethnicity.

${ }^{63}$ GON/MFSC. 'Forest Act 1993 and Forest Regulations 1995', edited by the Ministry of Forest and Soil Conservation. Kathmandu: Government of Nepal, 1995. The Act was proposed in 1993, published in 1995, and finally legalized in 1996. It is therefore usually represented as the Forest Act 1993 (1996). Shrestha, N. Kaji and Charla Britt. 'Crafting Community Forestry: Networking and Federation Building Experiences'. In Community Forestry at a Crossroads: Reflections and Future Directions in the Development of Community Forestry, edited by M. Victor, C. Lang and J. Bornemeier. Bangkok: Regional Community Forestry Training Centre, 1997, pp. 133-44. 
in the world because of the extent to which locally based user-groups are given autonomy over forest management and control over revenue, something that several early $\mathrm{CF}$ activists and high-level government officials each attribute to their own efforts. ${ }^{64}$ We believe that the government-which was closely connected to various political party networks that supported the move-also used the Act to demonstrate its difference from the previous Panchayat government. By devolving power to the local level, it was no doubt also influenced by donors such as UNDP who were helping to write decentralization legislation for Nepal at that time. ${ }^{65}$

What is important to recognize here is that all of these processes were at work in reshaping public authority around forest governance. There was a genuine desire for multiparty democracy and the decentralization of forest governance on the part of many different actors. There was also clear evidence from community forestry projects that local governance was more effective than governmental control. ${ }^{66}$ Finally, there was a potent coming together of interests across what were, at the time, newly empowered 'civil society' actors and political parties with the more traditional governmental elites and donor interests. The support of all these actors was crucial for the success of the 1993 (1996) Forest Act. It is in this sense that we see this Act as representative of the entrance of 'civil society' into public authority in Nepal after the 1990s, marking a departure from the Panchayat era.

Now community forestry is the most widespread and wellestablished of five different community-based forest management programmes in Nepal. ${ }^{67}$ It is a government provision that turns over the management of forests to locally based user-groups. Groups are constituted after the forest is demarcated (mapped) and an operational plan is approved by the district forest office, which continues to oversee the group. ${ }^{68}$ In practice, the degree to which the Department of Forests and/or donor-sponsored projects are engaged in the governance of individual user-groups is highly variable. What is particularly interesting about community forestry from a governance perspective is that user-groups are state-sanctioned-they have no legal right to manage forest resources without being recognized by

\footnotetext{
${ }^{64}$ Personal communication.

${ }^{65}$ Field notes.

${ }^{66}$ Gilmour and Fisher, Villagers, Forests and Foresters.

${ }^{67}$ Ojha et al., Communities, Forests and Governance.

${ }^{68}$ GON/DFRS. 'Master Plan for the Forest Sector of Nepal', edited by the Ministry of Forests and Soil Conservation. Kathmandu: Government of Nepal, 1998.
} 
the state as a formal user-group. ${ }^{69}$ But, CF user-groups are not considered part of the state-by themselves, by the Department of Forests, or by others. This was starkly evident during the conflict when $\mathrm{CF}$ user-groups and their infrastructure were often spared by the Maoists when most other government- and donor-supported groups and infrastructure were destroyed. ${ }^{70}$

\section{Federation of Forestry User-groups (FECOFUN): civil society and the exercise of public authority}

Alongside the development of CF in the 1990s, a group of donors also funded the formation of a networking institution. Working from a model of decentralizing development support, the network was designed to help share knowledge and experience across user-groups, on the assumption that this would lead to better governance. Local users were strongly supportive, especially in the east where the density of groups was highest. Donors justified their intention to provide financial and logistical support to emerging network leaders as a desire to spread CF across the nation. They supported gatherings of CFUG representatives between 1993 and 1995, including a national workshop in 1993 in which 40 CFUGs from 28 districts participated. These events enabled representatives of CFUGs from around the country to identify and recognize themselves as part of 'civil society' and of networks that had not been able to emerge under the Panchayat due to political repression.

The practices that set the boundary between society and state are quite profound here. User-groups that were promoted by the government, and ultimately dependent upon government recognition to be viable, transformed through the network into bodies distinct from the state, and often in open opposition to the state and the donors who helped form them. There was a clear realization among CFUG leaders of the need to promote and advocate for a community forestry agenda and users' rights. This needed to happen within national political

\footnotetext{
${ }^{69}$ See Lund, 'Access and Property', and Ribot, J. 'Representation, Citizenship and the Public Domain in Democratic Decentralization'. Society for International Development 50, no. 1 (2007), pp. 43-49.

${ }^{70}$ Maoist interference with CF was highly variable and took many forms. For a more detailed account, see Nightingale, Andrea and Jeevan Raj Sharma. 'Conflict Resilience Among Community Forestry User Groups: Experiences in Nepal'. Disasters

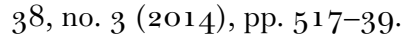


spheres, with CFUGs as representatives of 'society' that could pressure 'the state', as opposed to historical attempts by 'political parties' to pressure the 'the state'.

From this networking initiative, an NGO-the Federation of Forestry User-groups (FECOFUN)-emerged in 1995, with chapters in most districts and a central office in Kathmandu. Now, FECOFUN has established itself as the nation's largest civil society organization, representing about one-third of Nepal's population of 10 million, with federation chapters established in all of the country's 75 districts. As a result, it has emerged as a formidable political player at both the local and national levels, legitimated through its claim to represent 'civil society'. Its achievements include having successfully coordinated with other civil society groups in Nepal to block three consecutive attempts by the Ministry of Forest and Soil Conservation to amend the 1993 Forest Act (in 1998, 2008, and 2011). ${ }^{71}$

As a result of these successes, FECOFUN has been an important player within a sector that has seen a significant shift in actors who engage in public authority in Nepal. After the 1990 jana andolan and the opening up of more legal space for NGOs to take on the provision of development services as well as general freedom of association, the newly established and burgeoning 'civil society' sphere has demanded a voice in government policy processes. Activists have managed to institute the requirement to consult civil society whenever new strategic plans are being developed or significant new laws are passed. In the absence of such consultations - which generally require influential civil society groups to be invited to high-level meetings about new policies and laws-civil society networks will protest publically and seek to block these initiatives by the government. ${ }^{72}$

Despite this good news, FECOFUN has also transformed since its inception and recently it has been possible to identify several trends indicating that it faces several challenges and is not immune to pentangle politics. ${ }^{73}$ We note three challenges here. First, the entire innovation is framed within dominant imaginaries emerging from

\footnotetext{
${ }^{71}$ Sunam, Ramesh K., Naya S. Paudel and Govinda Paudel. 'Community Forestry and the Threat of Recentralization in Nepal: Contesting the Bureaucratic Hegemony in Policy Process'. Society \& Natural Resources 26, no. 12 (2013), pp. 1407-421.

${ }^{72}$ See Ojha et al., 'Policy Without Politics' for an exception in relation to climate policy.

${ }^{73}$ Ojha, Hemant Raj. 'Civic Engagement and Deliberative Governance: The Case of Community Forest Users' Federation, Nepal'. Contributions to Nepali History and Society 14, no. 2 (2009), pp. 303-34.
} 
international development, formal politics, forestry, and the market, which serve to shape how public authority is exercised by FECOFUN. ${ }^{74}$ These imaginaries mean that FECOFUN actors rarely challenge the incipient ideas of (respectively): notions of equitable distribution that dominate donor thinking ${ }^{75}$ the aligning of the network and user-groups to political parties in practice, even if this is publically hidden; scientific forestry (i.e. environmental management for timber production) $;{ }^{76}$ and the promotion of commercial products from forests. For example, FECOFUN's ability to claim legitimate authority in forest governance is limited by its discourses of representation that have been tied to hill communities and dominated by high-caste males. ${ }^{77}$ Attempts have been made to become more inclusive, but there is still significant 'internal exclusion'. ${ }^{78}$ As a result, FECOFUN has only partially challenged the institutions and practices through which public authority is exercised.

Second, in what is a well-worn form of public authority in Nepal, ${ }^{79}$ leaders and champions of FECOFUN draw patronage, recognition, and resources not from the wider community of people they claim to represent, but from powerful actors in the field of governancedonors, international agencies, and political parties-and thereby become entangled in the 'iron pentangle'. Here we see clearly aphno maanche dynamics at play as actors within FECOFUN align themselves with each other and with powerful donor and state actors to gain institutional recognition and, sometimes, material resources.

${ }^{74}$ Nightingale and Ojha, 'Rethinking Power and Authority'.

${ }^{75}$ Ojha, 'Civic Engagement and Deliberative Governance'.

${ }^{76}$ Nightingale, Andrea J. "“The Experts Taught us all we Know": Professionalisation and Knowledge in Nepalese Community Forestry'. Antipode 34, no. 3 (2005), pp. $5^{81-}$ 60.

${ }^{77}$ Ojha, Heman, R. 'Civic Engagement and Democratic Governance: The Case of Community Forest User Groups in Nepal'. In The Dynamics of Social Capital and Civic Engagement in Asia, edited by A. Deniere and H. Van Luong. London and New York: Routledge, 2012. Nightingale and Ojha, 'Rethinking Power and Authority'.

${ }^{78} \mathrm{On}$ exclusion within participatory processes, see Cooke, B. and Uma Kothari. Participation: The New Tyranny?. London: Zed Books, 2001. Korf, Benedikt. 'The Geography of Participation'. Third World Quarterly 31, no. 5 (2010), pp. 709-20. Young, Iris Marion. 'The Ideal of Community and the Politics of Difference'. In Feminism/Postmodernism, edited by Linda J. Nicholson. New York: Routledge, 1990, pp. 300-23.

${ }^{79}$ Bista, Dor Bahadur. Fatalism and Development: Nepal's Struggle for Modernization. Calcutta: Orient Longman, 1991. Gellner and Hachhethu, Local Democracy in South Asia. 
Third, their forms of collective action are structured around a formal organization, effectively centralizing discursive power and institutional resources in Kathmandu. This form of public authority has a veneer of inclusive representation from outside the state, but in practice, we see FECOFUN exercise public authority in somewhat contradictory ways. Older forms of authority are being reproduced (patronage, etc.) at the same time as FECOFUN represents a profound challenge to the centralized state, public authority as the exclusive domain of government actors, and the imaginary of the unified nation.

Furthermore, FECOFUN frames 'representation' in the language of 'user rights', reflecting a modernist, technocratic, ${ }^{80}$ global Northcentric notion of property rights through which equity is assumed to be achieved. ${ }^{81}$ The language of 'user rights' was politically friendly during the Panchayat regime because it avoided more contentious questions of how the state-society boundary was constructed and enacted on the ground. ${ }^{82}$ In other words, the Panchayat regime recognized that in order to achieve its goals of forest protection it had to give access to local people, but it stood firm in maintaining forests as property of the state and that governance should be overseen by the district forest offices. After 1990, user-groups gained more autonomy but they failed to secure control over the process of developing management plans and legal rights to the forest land itself. So while FECOFUN has successfully reshaped public authority over forests by demanding clearer, more secure user rights, they have not profoundly changed the top-down practices of public authority in this domain nor the government property rights which underpin such centralized control. They have failed to make the link between user rights and the need for users to have political rights to frame laws and operational plans affecting them (Ostrom calls these 'collective choice rights' ${ }^{83}$ ). As a consequence, the insistence on user rights dilutes citizens' collective rights and maintains the role of civil society in public authority over forests at the level of use (extraction), rather than instituting a profound redistribution to civil society of authority to govern forests.

\footnotetext{
${ }^{80}$ Ojha, Hemant R. Reframing Governance: Understanding Deliberative Politics in Nepal's Terai Forestry. New Delhi, India: Adroit Publishers, 2008.

${ }^{81}$ Cf. Ostrom, Elinor, Joanna Burger, Christopher B. Field, Richard B. Norgaard and David Policansky. 'Revisiting the Commons: Local Lessons, Global Challenges'. Science 284, no. 5412 (1999), p. 278.

${ }^{82}$ Mitchell, 'The Limits of the State'.

${ }^{83}$ Ostrom et. al. 'Revisiting the Commons'.
} 
The FECOFUN case thus illustrates well the ways in which civil society has both managed to change the character of public authority to require at least token attempts at inclusive representation and granting of public authority to non-state actors, and yet also repeats familiar forms. The achievements around user rights and the abilities of users to successfully fight key policy changes ${ }^{84}$ show how new institutions are influencing public authority in new ways. FECOFUN's ability to exercise public authority also marks a departure from the Panchayat era when influence over important policy and development practice was limited to elites within the government and the international donor apparatus. These departures have been achieved through new practices of claiming public authority such as successful demands to be at the political table when making policy, protest, national and international networking among diverse actors, media campaigns, and the articulation of an alternative governance agenda. At the same time, FECOFUN has also entrenched practices of patronage and, indeed, some of its successes have been dependent upon fostering aphno maanche relationships in the upper levels of government and within dominant political parties-practices which were used historically by those directly connected to the state. As a result, we see the same kind of space for civil society resulting from an unstable state, which Wedeen also found in Yemen. ${ }^{85}$ Yet we are cautious about overly celebrating this space as we find the boundary between civil society and the state to be changing (merging) as a result of groups like FECOFUN demanding a seat at the proverbial governing table. This dynamic is perhaps nowhere more obvious than in the notorious All Party Mechanism that emerged after 2008, to which we now turn.

\section{The changing nature of municipal governance and its stake in forestry}

An account of transitional governance in Nepal as seen through the lens of the forestry sector is incomplete without a brief mention of

\footnotetext{
${ }^{84}$ Ojha, Hemant R. 'The Evolution of Institutions for Multi-Level Governance of Forest Commons: The Case of Community Forest User Federations in Nepal'. Paper presented at the 'Sustaining Commons, Sustaining Our Future' IASC conference, Hyderabad, 2010.

${ }^{85}$ Wedeen, Lisa. 'Seeing Like a Citizen, Acting Like a State: Exemplary Events in Unified Yemen'. Comparative Studies in Society and History 45, no. 4 (2003), pp. 680-713. See also Byrne, "From Our Side Rules are Followed".
} 
how the governance of municipalities (villages) intersects with forest governance. Village development committees (VDCs) in rural Nepal underwent rapid changes in terms of governance practices, actors, and institutions that claim authority. This is primarily because they were without elected political representatives since 2004 when the king dissolved parliament until the 2017 local elections. In addition, the previous elections for VDCs were held in 1997, so at the time of writing, it had been 17 years since elections were held for local representatives. To simplify a very complex political moment, the king-who succeeded his brother after what many consider to be a bloody coup in 2002-dissolved parliament in the name of combating the insurgency in 2004. The Maoists People's War had gained significant traction by this time in many rural areas of Nepal. Most VDC presidents had fled to urban centres or had to hide on a regular basis from Maoist brigades. ${ }^{86}$ In short, the state had a very limited presence in many parts of Nepal during the war, and after the war its role remains under negotiation.

The Constituent Assembly general election held in 2008 served to elect representatives from the districts to a national parliament charged with both writing the new Constitution and undertaking the business of government. The votes were tallied at the VDC level, meaning that the percentage of support gained by individual political parties in each VDC was known, although the candidates were fielded at the constituency level (larger than the VDCs). After 2006, the Maoist interim government radically increased the budgets of VDCs, as part of demonstrating its commitment to various dimensions of their ideology. These budgets had been increased by earlier governments as well, but the amount of money flowing into local-level organizations now increased by orders of magnitude. ${ }^{87}$ Moreover, international donors also implemented reconstruction projects in consultation with VDC secretaries (bureaucrats) and locallevel political party representatives. This infusion of money had two effects: one to legitimate the local level as an appropriate context for governance and, two, to galvanize different actors and institutions to

\footnotetext{
${ }^{86}$ Pettigrew, Judith. 'Living Between the Maoists and the Army in Rural Nepal'. In Himalayan 'People's War': Nepal's Maoist Rebellion, edited by Michael Hutt. London: Hurst and Co., 2004. Pettigrew, Judith. Maoists at the Hearth: Everyday Life in Nepal's Civil War. Philadelphia: University of Pennsylvania Press, 2013. Thapa, A Kingdom Under Siege. Jha, Battles of the New Republic.

${ }^{87}$ GON/NPG. 'Interim Plan', edited by the National Planning Commission. Kathmandu: Government of Nepal, 2009.
} 
become invested in district development committee (DDG) and VDC level governance, even in the absence of local elected officials.

In order to administer this money, the All Party Mechanism (APM) emerged. APMs sprang up at the grassroots in 2007 as VDC secretaries sought a way to ensure cooperation from local political leaders as well as to ensure their own safety. ${ }^{88} \mathrm{APMs}$ at the VDG and DDG levels began as advisory bodies, and comprised representatives from political parties that had earned representation in the Constituent Assembly from the locality. It was subsequently written into law (2009) ${ }^{89}$ and almost as quickly revoked again (January 2012) when reports of corruption proliferated. To date, civil servants are legally doing the everyday business of government as VDC secretaries, chief executive officers in municipalities (urban areas), and local development officers (at DDG level), but in practice the APM continues to operate in most places and includes local civil society leaders (always affiliated with a particular party) ${ }^{90}$ and members of marginalized groups (also party affiliated). This is not particularly surprising - as one former VDC president said in an interview, he 'always consulted all his friends' (meaning leaders of the other political parties) when making decisions, beginning in the early 1990s. Now, in most places, the political parties collect a share (proportional to their local representation) of development resources and state contracts by ensuring 'user-groups' run by their party members are selected for development and local governance projects, such as road building, at the local level.

Within this context, a variety of collaborations and competitions between VDGs, CF user-groups, FECOFUN, and other civil society groups emerged. First, over the last ten years at least, there has been an increasing national narrative about the need for the VDC-or after 2017 , the newly formed municipalities-to administer CF funds. Community forest user-groups are able to raise significant income from the sale of harvesting permits. This income has been important in terms of keeping local people invested in what are otherwise voluntary $\mathrm{CF}$ activities, including annual meetings and patrolling forest areas for poachers. But it is also 'public' money that is accessible only to those

\footnotetext{
${ }^{88}$ Field notes and Byrne and Shrestha: 'A Compromising Consensus?'.

${ }^{89}$ Interim Constitution, article no. 139, November 2009.

${ }^{90}$ Political parties do not have clear positions in relation to forests and forest governance. Rather, the political parties to which civil society leaders affiliate themselves at different levels is strongly shaped by which parties are more influential in which geographic regions as well as their aphno maanche relationships.
} 
within the user-group, which does not necessarily include everyone living within a particular locality. This combination of large funds and exclusion of some local residents led the national Federation of Village Development Committees ${ }^{91}$ to demand that a significant portion of CF funds should be given to the VDG to redistribute fairly. In particular, this federation of local government bodies was keen to think about national redistribution. As one of its members said in a 2010 interview when discussing CF:

... there is no way to work without the communities ... But another aspect, when you say community forestry, and when that community understands in a wrong way that it is the only one to have all the rights, then there is a problem ... Any one child in Ilam [District] should get to study from the share of a planted tree in Mugu [District]. The subject of how to manage that is complex. That is the reason why we need the centre government to manage that. [The centre government] might say, 'I will give the resource from the forest of Mugu to a child from a poor family of Ilam for his/her studies' and send it.

While this sounds reasonable and 'democratic', very few observers on the ground believe that such a system would lead to fair redistribution. Rather, it is seen as a way for (a) local governments to try to assert authority over CF user-groups-who has authority is unclear as CFUGs and local governments are governed by different and somewhat contradictory laws; and (b) as a mechanism for corrupt VDC secretaries and political party leaders to control and siphon off CF funds. It should be noted that many CF user-groups are already politicized and influenced by party politics, but the structure of the committees is such that in many places, party politics is somewhat less overriding as a mechanism of fund allocation than it is in the VDC context. ${ }^{92}$ We also believe that the Federation of VDGs itself was an attempt at a fairly radical redistribution of public authority, despite languishing due to the lack of local elections. It was effectively a national network of local governments that attempted to lobby on national issues, with potentially significant implications for public authority, and was emblematic of the fracturing of authority. Local governments banding together to have a national influence spotlights the way in which different levels of government do not necessarily

\footnotetext{
${ }^{91}$ This federation is itself a fascinating hybrid of a government-sponsored, donorsupported, independent NGO.

${ }_{92}$ Nightingale, “"The Experts Taught us all we Know"'.
} 
work in close collaboration nor even see themselves as part of one big entity called 'the state'.

In addition, many climate change adaptation and mitigation programmes have been sceptical of engaging VDCs because of the lack of elected officials and the problems of corruption associated with the informal APM institutions. Rather, many 'community-based adaptation' programmes singled out the forestry sector as a key domain for involvement in new programmes. ${ }^{93}$ And in particular, in many places community forestry user-groups are considered to be the most equitable and reliable local institutions, and therefore donor-sponsored programmes are choosing to implement their projects directly through them. This has significant implications for transitional politics. Not only are non-governmental institutionsCFUGs-being authorized to engage (at least in part) in the governance of forest resources, but that mandate is now expanding to include other multisectorial dimensions as well. For example, in eastern Nepal, GFUGs have used adaptation funds to build paper factories and invest in tea plantations in order to engage in alternative markets.

And to add to the complexity of actors and institutions being authorized to govern resources in the name of climate change adaptation, in the Terai, a donor-sponsored forestry programme designed new institutions through which to implement climate change programmes: village forestry coordination committees (VFCGs). The Local Self Governance Act (1999) has a provision for the coordination of forestry groups through something called the District Forestry Coordination Committee (DFCG) but not VFCGs. The DFCG is a direct response to the need to coordinate across dispersed usergroups and we speculate it was perhaps also an attempt to either make FECOFUN a part of the state or to compete with FECOFUN's growing influence. While the war more or less halted the institution of DFGGs, in the post-2008 period they are again on the agenda, albeit somewhat subsumed under the new District Energy and Environment Coordination Committees (DEECG). These new institutions created another layer of forest governance at the district level and serve to

\footnotetext{
${ }^{93}$ Nightingale, Andrea J. 'A Socionature Approach to Adaptation: Political Transition, Intersectionality, and Climate Change Programmes in Nepal'. In Climate Change Adaptation and Development: Transforming Paradigms and Practices, edited by Tor Håkon Inderberg, Siri Eriksen, Karen O'Brien and Linda Sygna. London: Routledge, 2015, pp. 219-34. Ojha et al., 'Policy Without Politics'.
} 
authorize new actors outside the traditional domains of forestry who can shape the affairs of individual user-groups. While it remains to be seen what impact they have on the ground, and the 2017 local elections reconfigured these bodies again, for our argument here the important point is the way in which government bodies, NGOs, donor-sponsored projects, and political parties are all engaged in the process of governing forests. CF user-groups no longer operate more or less independently with support from the district forest office, an international donor project, and FECOFUN-as they were first conceived. Rather, they are part of a political field of diffuse public authority spread across a range of actors who seek legitimacy by recognition not only from the state, but also from each other. In the last few years we have seen collaboration over quasi-legal or illegal extraction of forest resources (timber and medicinal herbs) to be one of the key ways in which such recognition is practised within these 'iron pentangles'.

These examples show how public authority finds creative and 'ad hoc' ways to govern in the midst of legal uncertainties and lack of elected officials. At the same time, they also show how these practices tend to follow rather predictable patterns. Patronage relations extend well back to the Rana times, and when the state itself appears to be receding, patronage and 'iron pentangle' politics re-emerge as the way in which actors seek to control the resources of the statewhether that be VDC budgets or CF resources. As such, we see a rather radical reformation of public authority in Nepal. It is no longer the Department of Forests or village mukiya who control the everyday governance of forests. At the same time, we also see that new actors entering the business of governing tend to draw on both new and old discourses and practices in order to exercise public authority.

\section{Conclusion}

This article began with a quote from a Nepali intellectual in 2010 about the state being un-built. At that time-and even more so nowwe strongly contest that idea. Rather, this article has argued that the Nepali state is being (re)built, perhaps just not along the lines of what might be imagined, given the aspirations for 'the new federal republic of Nepal' articulated by political parties and many groups within and outside the country. Through the lens of forest governance, we have sought to illuminate the diffuse actors, institutions, and practices 
at subnational scales through which public authority is achieved in everyday contexts.

On the one hand, we have often found ourselves bewildered and struggling to identify the pattern of political relations, which began with the 1990s' move to multiparty democracy and have been open for negotiation in Nepal since at least 2006. (We do not want to place too much emphasis on the end of the war as marking a disjuncture in governance, although certainly it was an important legal and political moment.) On the other hand, we have also been concerned to see the repetition and, indeed, cementing of familiar and rather insidious practices through which public authority is exercised and recognized. These include patronage (aphno maanche and political party networks) and the assertion of state authority, when the intention is personal profit (such as misdirection of DDC, VDC, and CF funds). Added to these, the media is filled with accounts of intimidation and violence used to win VDC and DDC contracts or to engage in illegal activities. In short, public authority is being exercised by a wider range of actors using some of the tactics that were hidden behind a carefully maintained 'counterfeit reality' during the pre-1990 period.

Our historically situated account has allowed us to see more clearly the ways in which public authority has been fragmented, but also how that fragmentation has enrolled some rather predictable actors: political elites and international donors, along with the entry of new ones such as activist groups, national civil society networks, and more ephemeral volunteer networks. Here, we have also seen the establishment of new institutions, including those within the state (DFCG and DEECG), in civil society (like FECOFUN and community user-groups), donor-sponsored VFCGs, and multistakeholder platforms that bring these actors together (APM). These institutions and actors have largely used an even more predictable set of practices: user-group meetings, consensus building, patronage, creative (mis) use of funds, and violence. We want to make it clear that there are well-established antecedents for most of these in Nepalese politics, both those practices that are celebrated as positive harbingers of democracy to come, and those which are lamented as undermining the establishment of a legitimate state regime. What we find most interesting about this fracturing and cementing is that, while the use of patronage and violence might be quite effective for leveraging state resources or winning contracts, it is also undermining the legitimacy of the actors who use those tactics. After 2011 , people began to talk openly and more vehemently about the rampant corruption around 
the awarding of contracts with government funds and the lack of accountability among those elected to represent 'the people' in the Constituent Assembly.

Because of the complexity and fluidity of these 'iron pentangle' relations, this account should not be read as one that can predict the trajectory of state formation in Nepal. Rather, we offer an account that points to the importance of an ethnography of governing wherein we see moments of state formation in action. These moments are highly contested. The case of FECOFUN demonstrates such stochastic processes: what began as a donor-dependent network, transformed into a bottom-up activist movement for user-group rights, which subsequently lost some of its legitimacy by becoming entrenched in political party struggles and being co-opted into some of the government policy-making processes it sought to criticize. At the same time, FECOFUN remains an important and powerful political actor at the national and grassroots levels, able to exercise legitimate public authority and to do so in a manner that is considered 'outside the state'. So it is not possible to place the network and its practices in terms of public authority in one category. Rather, by focusing on the actors, institutions, and practices of governing, our account provides signposts for the nature of public authority and how it is diffused across a range of actors. The outcome of the state-building project in Nepal remains in transition, but we would like to suggest that more attention is paid to how governing is achieved across Nepal at all levels, in addition to the political wrangling of the parties and elites in Kathmandu. 